\title{
Reading Strategy Instruction in Saudi Schools
}

\author{
Hashem Ahmed Alsamadani \\ College of Education, Um-Alqura University, P.O. Box 715 Makkah - Saudi Arabia \\ Email: hmazawid@gmail.com
}

\begin{abstract}
This study explores the attitudes of Saudi EFL teachers toward explicit instruction of reading strategies. The study also compares actual practices of Saudi teachers with their beliefs and attitudes toward reading strategy instruction. In this study, quantitative data were collected using an attitude questionnaire, while qualitative data were collected using observation and semi-structured interviews. The quantitative data obtained were analyzed by using means, standard deviations, and the Pearson product-moment correlation coefficient. Qualitative data from a semi-structured interview were also analyzed to explore teachers' knowledge about reading strategy instruction. The results of this study show that Saudi teachers believe strongly in the importance of cognitive reading strategies and that they have insufficient knowledge of the importance of metacognitive reading strategies. The study ends with recommendations for training Saudi EFL teachers in some of the most effective metacognitive reading strategies to help students plan, monitor, evaluate, and regulate their learning.
\end{abstract}

Index Terms - ESL/EFL reading, reading strategies, strategy instruction

\section{INTRODUCTION}

Reading has been the most emphasized skill throughout the last three decades of second/foreign language teaching research (Susser, Robb, 1990). In today's classrooms, EFL reading instruction is moving increasingly from teaching texts to teaching readers how to comprehend texts (Haas \& Flower, 1988). In other words, EFL teachers focus on teaching reading strategies for understanding content elements, textual features, rhetorical elements, and cultural background (Hamp-Lyons, 1985; Mikulecky, 1985; Pakenham, 1984 \& Susser, Robb, 1990).

From this researcher's point of view, which has developed out of seven years of experience as a teacher of EFL, a supervisor of EFL, and later as an assistant professor of EFL curriculum and instruction at Umm Alqura university, EFL teaching practices in Saudi schools tend not to focus on reading skills and strategies. Rather, EFL teachers spend time allocated for reading on practicing "silent reading" and "comprehension questions".

Because of this gap between the world's rapid movements toward teaching reading skills and strategies and the reality of reading instruction in Saudi Arabia, this researcher decided to conduct a study exploring EFL teachers' attitudes toward teaching certain essential reading strategies, both cognitive and metacognitive. This study also explores the reality of teaching reading in Saudi schools by observing and interviewing a sample of Saudi EFL teachers.

\section{LITERATURE REVIEW}

Cognitive strategies aid readers in constructing meaning from the text. Studies in first language and second language reading research have classified cognitive strategies as bottom-up and top-down (Block, 1986; Carrell, 1989; Davis \& Bistodeau, 1993). During reading, readers engage constantly in a variety of cognitive processes. Using bottom-up strategies, readers process information at the word and sentence levels. At this stage, they focus on identifying the meaning and grammatical category of a word, sentence syntax, and text details (Aebersold and Field, 1997). By using top-down strategies, such as background knowledge, prediction, and skimming, readers check to see how this information fits in their schemata. Dole, Nokes, and Drits (2009) have provided an especially thorough analysis of landmark studies that have influenced the instruction of cognitive reading strategies.

Metacognitive strategies function in monitoring or regulating cognitive strategies (Devine, 1993; Flavell, 1981). In other words, metacognitive strategies are relevant specifically to comprehension (Dole, et.al, 2009). Examples of these strategies include checking the outcome of any attempt to solve a problem, planning the next move, monitoring comprehension, testing, revising, and evaluating strategies (Baker \& Brown, 1984). Metacognitive reading strategies, therefore, aid EFL learners in being consciously aware of what they learn, how they learn, and how they can use new knowledge in different situations.

In L1 and L2 contexts, many studies have focused on the use of cognitive strategy instruction and the effects of metacognitive strategy instruction on reading. In a pioneering study, Palincsar and Brown (1984) analyzed the effects of helping young L1 students by teaching them to monitor comprehension. They gave this instruction the name "reciprocal teaching". In reciprocal teaching, the teacher models four strategies: clarifying, identifying the main idea of a section of text, summarizing, and predicting. After that, students are divided into groups, to whom specific students, who have been assigned to be teachers, model the use of these four strategies. Results of the study showed that at the end of instruction, the experimental group scored higher than the control group in the final comprehension test. 
Five years later, Carrell, Pharis, and Liberto (1989) conducted a study to examine the combined effects of cognitive and metacognitive strategy instruction on reading comprehension. In order to activate students' background knowledge, they were trained in two strategies: semantic mapping and the experience-text-relationship (ETR). In addition, each group was trained in how to regulate and be aware of these two strategies. Results indicated that metacognitive and cognitive strategy instruction were effective in enhancing reading comprehension regardless of students' reading proficiency levels.

Cubucku (2008) investigated the effectiveness of metacognitive strategy instruction on students' reading comprehension. In his study, a sample of 130 undergraduate students were divided into experimental and control groups. The experimental group received explicit strategy instruction, while the control group received none. The results showed a significant difference in the comprehension levels between the two groups in favor of the experimental group. Recently, Akkakoson and Setobol (2009) tested the effects of explicit metacognitive reading strategy instruction on Thai students' reading comprehension. The study revealed that high-, mid-, and low-level readers scored higher in their post-test than in their pre-test. This result means that explicit reading strategy instruction has a great impact on students' comprehension regardless of proficiency level.

In a recent study, Wichadee (2011) examined the effectiveness of explicit instruction of metacognitive strategies on Thai students' reading comprehension scores. A metacognitive questionnaire as well as a reading test were administered at the beginning and at the end of the course for the ascertainment of any changes in both the questionnaire responses and test scores. A semi-structured interview was also conducted to explore students' views on the strategy-based instruction. Results showed that after the instruction, the reading score and metacognitive strategy use of the three groups (high, moderate, and low) were significantly higher than before the instruction.

Finally, reading strategy instruction has proven to be effective not only in developing reading comprehension, but also in expanding vocabulary size. In this regard, Rasekh and Ranjbary (2003) studied the effects of reading strategy instruction on the development of EFL students' lexical knowledge. The study revealed the significant positive impact that explicit strategy instruction had on the students' vocabulary size.

Moreover, Mizumoto and Takeuchi (2009) examined the effectiveness of explicit instruction of vocabulary learning strategies (VLSs) on a group of 146 female Japanese EFL learners. The researchers used the quasi-experimental design in which they administered a vocabulary test and questionnaires on VLSs. Based upon the results of the vocabulary test, participants were divided into two groups: an experimental group and a control group. The experimental group received explicit instruction on VLSs combined with their regular language lessons, while the other group received traditional language lessons. The results showed that the experimental group scored higher than the control group on the vocabulary test. They also indicated that strategy instruction was effective in changing the repertoire of strategies used and improving their frequency of use.

Moreover, strategy training increased the use of certain strategies more than it did for other strategies. In a study about the role of reading teachers, Pressley and Afflerbach (1995) argued that ESL/EFL teachers should model three types of reading strategies: Before-reading strategies (planning), while-reading strategies (monitoring), and afterreading strategies (evaluating). This would aid EFL/ESL students in constructing meanings, planning, monitoring, and evaluating comprehension (Israel, 2007).

All of the above research findings concur on one fact: reading strategy instruction and training clearly enhance students' level of comprehension in both L1 and L2. The current study builds on this fact to argue that Saudi EFL teachers should devote time to train and teach their students on how to utilize these strategies for better comprehension. The research findings that support strategy instruction will also be used to reject the null hypothesis $\left(\mathrm{H}_{\mathrm{o}}\right)$ : There is no significant statistical difference in reading comprehension scores between students who were trained in using reading strategies and those who were not.

The current study, however, differs from the studies mentioned above in that it utilizes a triangulation approach in collecting data. The researcher first collects quantitative data about Saudi teachers' beliefs and attitudes toward the explicit teaching of reading strategies. The researcher then investigates further the reality of reading strategy instruction in Saudi classes by observing a sample of 10 teachers in their reading classes. Finally, the study will explain why reading strategy instruction is or is not common practice in Saudi schools though interviewing 4 Saudi teachers in a semi-structured interview.

\section{PURPOSE OF THE STUDY}

This study aims at examining Saudi EFL teachers' attitudes toward explicit teaching of metacognitive and cognitive reading strategies. It also explores the obstacles that EFL teachers might encounter when trying to teach these strategies. The purpose of the study can be summarized as follows:

1. To explore Saudi EFL teachers' attitudes toward reading strategy instruction.

2. To learn about actual practices of reading instruction in Saudi schools.

3. To determine the relationship between teachers' degrees of qualification and their attitudes toward reading strategy instruction. 
This study is a significant means of learning about Saudi teachers' beliefs and attitudes toward reading strategy instruction. Squires and Bliss (2004) assert that "decades of research on the connection between teachers' theoretical beliefs and their practices yield a common theme: All teachers bring to the classroom some level of beliefs that influence their critical daily decision making" (p.756). Therefore, teachers' practices in classrooms and their decisions regarding teaching are all guided by what they believe in and value most.

The current study is also significant in obtaining clear knowledge about the real practices of Saudi EFL teachers when teaching reading. Spencer, Carter, Boon, and Simpson-Garcia (2008) concluded that research findings have proven the great significance of explicit strategy instruction in developing reading skills. Additionally, Park and Osborne (2006) have cited numerous studies showing that instruction using reading strategies is the most effective means of increasing student comprehension and developing skilled readers.

Therefore, by understanding teachers' attitudes toward teaching reading strategies and their actual practices in classrooms, one can clearly tell whether the teaching/learning process is proceeding properly. If teachers' attitudes are distant from their practices, If teachers' attitudes are distant from their actual practices, this could indicate that something is amiss that might undermine the entire process. Thus, the whole system of language instruction, including teacher preparation programs and in-service training programs should be revisited, re-evaluated and redefined. This study is also significant in designing EFL training courses. With an understanding of how teachers perceive reading strategies and how often they teach them, an effective course with well-defined objectives can be recommended and designed.

\section{METHODOLOGY}

\section{A. Research Questions}

The present study aims to answer the following questions:

1. What are the attitudes of Saudi EFL teachers toward the explicit teaching of reading strategies in Saudi EFL classrooms?

2. How often do Saudi EFL teachers teach these strategies?

3. Is there a significant relationship between the qualifications of teachers and their attitudes toward teaching reading strategies?

\section{B. Participants}

The research sample consisted of 60 male Saudi EFL teachers from the Makkah and Allith regions in Saudi Arabia. The sample represented the $80 \%$ return rate of the survey. Teachers' qualifications ranged between BA and MA and their teaching experiences ranged between 2-10 years. After collecting and analyzing the survey data, the researcher selected 10 teachers to observe based on the diversity of answers they gave in the questionnaire. All visits were planned in advance so as not to confuse teachers' schedules. Finally, the researcher interviewed four Saudi teachers to learn more about their knowledge and views about reading strategy instruction. Each interview lasted for $10-15$ minutes.

\section{Instruments}

The main instrument of this study was the attitude questionnaire, which was developed by the researcher and judged for content and face validity by five college-level English teachers at Umm Alqura University. In this questionnaire, the researcher compiled the most common and widely cited cognitive and metacognitive reading strategies in a five-point Likert Scale survey.

The head instruction reads as follows: Indicate the extent to which you agree on the importance of explicit teaching of each of the following reading strategies. The participants were asked to indicate their response on a scale of "strongly agree" (SA), "agree" (A), "neutral" (N), "disagree" (DA), and "strongly disagree" (SD).

To answer the second research question, the researcher used the same questionnaire as a checklist during his classroom visits. In each visit, the researcher marked how often teachers teach students in each reading strategy on a 5point scale of "never", "occasionally", “ sometimes", "often”, and "always".

Finally, semi-structured interviews were conducted with four Saudi EFL teachers to determine the extent of their knowledge about reading strategies. Each interview lasted $10-15$ minutes during which time the researcher took notes on the information teachers gave about cognitive/metacognitive reading strategy instruction. The general discussion questions were:

- Tell me all you know about cognitive and metacognitive reading strategies.

- How feasible is it to teach/train students in these strategies?

Results of the interviews will be reported in the "Discussion" section to explain the quantitative/qualitative results of the research questions.

\section{Data Collection}

To address the research questions, the researcher designed a questionnaire including some of the most common and effective reading strategies. These reading strategies included: 
1. Cognitive strategies, bottom-up and top-down strategies, such as prediction, modification, translation, skimming, scanning, etc.

2. Metacognitive strategies, such as checking one's comprehension, revising, testing and evaluating one's strategies.

A mixed methodology design was employed because both qualitative and quantitative data were collected. Quantitative forms of data were collected first from scaled survey responses. The research participants were asked to decide to what extent they agreed with the importance of explicit teaching of each strategy on a scale of strongly agree, agree, neutral, disagree and strongly disagree.

Qualitative data were collected from observing $10 \mathrm{EFL}$ teachers in their reading classes. The researcher visited 10 English language teachers during their reading classes to investigate the degree of use of each strategy. The researcher indicated how often teachers used each strategy on a 5-point scale of never, occasionally, sometimes, often, and always. The main purpose of observation was to view real practices in classes and to compare them with teachers' beliefs.

Finally, the researcher interviewed 4 teachers in semi-structured interviews. The aim of these interviews was to learn more about what teachers knew about reading strategies. The interview questions also aimed to explore the feasibility of teaching/training students on the use of these strategies.

\section{FINDINGS}

\section{A. First Research Question}

To answer the first research question ("What are the attitudes of Saudi EFL teachers toward the explicit teaching of reading strategies in the EFL classroom?"), the researcher calculated descriptive statistics using SPSS version 17. Table1 shows the means and standard deviations for each reading strategy.

TABLE 1:

MEANS AND STANDARD DEVIATIONS FOR READING STRATEGIES

\begin{tabular}{llcc}
\hline Strategies & N & Mean & Std. Deviatior \\
\hline Strategy 01 & 60 & $\mathbf{4 . 6}$ & .58 \\
Strategy 04 & 60 & $\mathbf{4 . 3}$ & .78 \\
Strategy 17 & 60 & $\mathbf{4 . 2}$ & .96 \\
Strategy 05 & 60 & $\mathbf{4 . 2}$ & .73 \\
Strategy 03 & 60 & $\mathbf{4 . 2}$ & .69 \\
Strategy 11 & 60 & $\mathbf{4 . 1}$ & .94 \\
Strategy 10 & 60 & $\mathbf{4 . 1}$ & 1.16 \\
Strategy 09 & 60 & $\mathbf{4 . 0}$ & 1.03 \\
Strategy 20 & 60 & 3.8 & .89 \\
Strategy 06 & 60 & 3.8 & 1.08 \\
Strategy 25 & 60 & 3.8 & .98 \\
Strategy 26 & 60 & 3.8 & 1.37 \\
Strategy 07 & 60 & 3.7 & .98 \\
Strategy 23 & 60 & 3.7 & 1.06 \\
Strategy 11 & 60 & 3.7 & 1.28 \\
Strategy 02 & 60 & 3.7 & 1.54 \\
Strategy 24 & 60 & 3.6 & 1.15 \\
Strategy 15 & 3.6 & 1.17 \\
Strategy 08 & 60 & 3.6 & .95 \\
Strategy 13 & 60 & 3.5 & 1.03 \\
Strategy 19 & 60 & 3.4 & 1.17 \\
Strategy 18 & 60 & 3.4 & 1.28 \\
Strategy 12 & 60 & 3.3 & .95 \\
Strategy 14 & 60 & 3.3 & 1.13 \\
Strategy 21 & 60 & 3.2 & 1.14 \\
Strategy 22 & 60 & 3.1 & .96 \\
Strategy 27 & 60 & 1.23 \\
\hline
\end{tabular}

It is clear from Table1 that Saudi teachers have positive attitudes towards reading strategy instruction. Almost all participants agreed (means $4 \rightarrow$ ) on the importance of the following explicit teaching of strategies: $1,4,17,5,3,11,10$, and 9. These strategies were:

- Previewing the reading martial by thinking about the text, the title, and the pictures. (1)

- Skimming and scanning the text. (4)

- Guessing the meaning of unknown words. (17)

- Asking questions about the text before reading it. (5)

- Activating students' prior knowledge and experiences. (3)

- Paraphrasing what students read. (11)

- Using context clues to help students understand what is being read. (10)

- Using tables, figures, and pictures to increase understanding. (9)

Conversely, participants were not certain (or did not know) about the importance of teaching the other 19 strategies. These strategies were: 
- Having a purpose for reading. (Met.)

- Asking questions about the text before reading it. (Cog.)

- Writing summaries to reflect on key ideas in the text. (Cog.)

- Underlining or circling information in the text to help students remember it. (Cog.)

- Stopping reading to check comprehension. (Met.)

- Modifying new learning. (Met.)

- Checking students' understanding when coming across conflicting information. (Met.)

- Thinking aloud while reading. (Cog.)

- Rereading the problematic part. (Cog.)

- Looking up unknown words in a dictionary. (Cog.)

- Discussing a student's reading with others to check understanding. (Met.)

- Providing feedback on what a student has read. (Met.)

- Making inferences and drawing conclusions. (Met.)

- Comparing and contrasting information from one or more texts. (Met.)

- Concentrating on the reading task. (Met.)

- Regulating mood to stimulate the reading process. (Met.)

- Analyzing and evaluating the information presented in the text. (Met.)

- Engaging with the text. (Met.)

- Integrating the information in the text with what the student already knows. (Met.)

- Completing graphic organizers such as the Venn diagrams, KWL, etc. (Met.)

\section{B. Second Research Question}

The second research question was the following: "How often do Saudi EFL teachers teach these strategies?" In order to answer this question, the researcher collected qualitative data by observing 10 Saudi EFL teachers while they were teaching reading at different secondary levels. Each teacher was visited once and each visit lasted 40 minutes, during which time the researcher noted the frequency at which each teacher trained/taught students in one of the reading strategies included in the questionnaire. The researcher used a 5-point scale of never, occasionally, fairly, often, and always. Table 2 shows the frequencies of use for each reading strategy.

TABLE 2:

FREQUENCY OF USE FOR READING STRATEGIES

\begin{tabular}{|c|c|c|c|c|c|}
\hline & \multicolumn{5}{|c|}{ Frequency of Use } \\
\hline & Never & Occasionally & Sometimes & Often & A lways \\
\hline Strategy 01 & $02 \%$ & $08 \%$ & $22 \%$ & $13 \%$ & $\mathbf{5 5} \%$ \\
\hline Strategy 02 & $15 \%$ & $00 \%$ & $23 \%$ & $10 \%$ & $\mathbf{5 2} \%$ \\
\hline Strategy 03 & $08 \%$ & $02 \%$ & $12 \%$ & $\mathbf{5 5} \%$ & $23 \%$ \\
\hline Strategy 04 & $08 \%$ & $08 \%$ & $12 \%$ & $17 \%$ & $\mathbf{5 5} \%$ \\
\hline Strategy 05 & $08 \%$ & $07 \%$ & $08 \%$ & $\mathbf{5 0} \%$ & $26 \%$ \\
\hline Strategy 06 & $08 \%$ & $21 \%$ & $33 \%$ & $28 \%$ & $10 \%$ \\
\hline Strategy 07 & $10 \%$ & $13 \%$ & $17 \%$ & $\mathbf{5 0} \%$ & $10 \%$ \\
\hline Strategy 08 & $20 \%$ & $08 \%$ & $20 \%$ & $34 \%$ & $18 \%$ \\
\hline Strategy 09 & $15 \%$ & $03 \%$ & $12 \%$ & $\mathbf{5 0} \%$ & $20 \%$ \\
\hline Strategy 10 & $15 \%$ & $10 \%$ & $23 \%$ & $30 \%$ & $21 \%$ \\
\hline Strategy 11 & $08 \%$ & $31 \%$ & $18 \%$ & $28 \%$ & $15 \%$ \\
\hline Strategy 12 & $10 \%$ & $17 \%$ & $38 \%$ & $23 \%$ & $12 \%$ \\
\hline Strategy 13 & $10 \%$ & $15 \%$ & $33 \%$ & $20 \%$ & $22 \%$ \\
\hline Strategy 14 & $15 \%$ & $22 \%$ & $37 \%$ & $22 \%$ & $04 \%$ \\
\hline Strategy 15 & $02 \%$ & $20 \%$ & $10 \%$ & $53 \%$ & $15 \%$ \\
\hline Strategy 16 & $00 \%$ & $22 \%$ & $45 \%$ & $20 \%$ & $13 \%$ \\
\hline Strategy 17 & $08 \%$ & $12 \%$ & $07 \%$ & $38 \%$ & $35 \%$ \\
\hline Strategy 18 & $07 \%$ & $18 \%$ & $27 \%$ & $32 \%$ & $16 \%$ \\
\hline Strategy 19 & $75 \%$ & $10 \%$ & $15 \%$ & $00 \%$ & $00 \%$ \\
\hline Strategy 20 & $90 \%$ & $10 \%$ & $00 \%$ & $00 \%$ & $00 \%$ \\
\hline Strategy 21 & $95 \%$ & $05 \%$ & $00 \%$ & $00 \%$ & $00 \%$ \\
\hline Strategy 22 & $100 \%$ & $00 \%$ & $00 \%$ & $00 \%$ & $00 \%$ \\
\hline Strategy 23 & $100 \%$ & $00 \%$ & $00 \%$ & $00 \%$ & $00 \%$ \\
\hline Strategy 24 & $\mathbf{5 0} \%$ & $10 \%$ & $30 \%$ & $10 \%$ & $00 \%$ \\
\hline Strategy 25 & $85 \%$ & $10 \%$ & $05 \%$ & $00 \%$ & $00 \%$ \\
\hline Strategy 26 & $100 \%$ & $00 \%$ & $00 \%$ & $00 \%$ & $00 \%$ \\
\hline Strategy 27 & $85 \%$ & $10 \%$ & $05 \%$ & $00 \%$ & $00 \%$ \\
\hline
\end{tabular}

Using a frequency of $50 \%$ as a cutoff point, table 2 shows that teachers always used strategies 1 ( previewing the reading materials by thinking about the text, the title, etc.) and 4 (skimming and scanning the text). This result is consistent with the results of quantitative data in which strategies 1 and 4 were ranked as the most important strategies to teach. However, observations revealed that teachers always taught their students the second strategy (having a purpose for reading), which was not considered to be important in the quantitative data. 
Table 2 also shows that participants often used strategies 15 (rereading the problematic part), 3 (activating prior knowledge), 5 (asking questions about the text before reading), 7 (underlining or circling information), and 9 (using tables, figures, etc.). This result is also consistent to some extent with the quantitative data. Strategies 3, 5, and 9 were additional strategies that participants agreed upon as being important. This finding shows that participants' practices are most likely the same as their beliefs and attitudes, which confirms the findings of Squires and Bliss (2004).

However, the results of the second research question reveals that other strategies were rarely, occasionally, or never practiced in Saudi reading classes. These strategies were as follows:

- Having a purpose for reading. (Met.)

- Writing summaries to reflect on key ideas in the text. (Cog.)

- Underlining or circling information in the text as a memory aid. (Cog.)

- Stopping reading to check comprehension. (Met.)

- Modifying new learning. (Met.)

- Checking one's understanding when coming across conflicting information. (Met.)

- Thinking aloud while reading. (Cog.)

- Looking up unknown words in a dictionary. (Cog.)

- Discussing one's reading with others to check understanding. (Met.)

- Providing one's own feedback on what one has read. (Met.)

- Making inferences and drawing conclusions. (Met.)

- Comparing and contrasting information from one or more texts. (Met.)

- Concentrating on the reading task. (Met.)

- Regulating mood to stimulate the reading process. (Met.)

- Analyzing and evaluating the information presented in the text. (Met.)

- Engaging with the text. (Met.)

- Integrating the information in the text with what one already knows. (Met.)

- Completing graphic organizers such as Venn diagrams, KWL, etc. (Met.)

- Guessing the meaning of unknown words. (Cog.)

- Paraphrasing what students read. (Cog.)

- Using context clues to help in understanding what is being read. (Cog.)

\section{Third Research Question}

The third research question was the following: "Is there a significant relationship between the qualifications of teachers and their attitudes toward teaching reading strategies?" The null hypothesis was:

$\mathrm{H}_{\mathrm{o}}$ : There is no significant relationship between the qualifications of teachers and their attitudes toward reading strategy instruction.

To test this hypothesis, the relationship between the degree of teachers' qualifications and their attitudes toward teaching reading strategies was investigated using the Pearson product-moment correlation coefficient. Preliminary analyses were performed to ensure no violations of the assumption of normality, linearity and homoscedasticity. The results shown in table 3 show that we do not reject the null hypothesis that there is no significant relationship between teachers' qualifications and their attitudes toward reading strategy instruction.

TABLE 3:

PEARSON-PRODUCT CORRELATION

\begin{tabular}{llll}
\hline \hline & & Qualification & Total score \\
\hline Qualification & Pearson Correlation & 1 & -.204 \\
& Sig. (2-tailed) & & .118 \\
& $\mathrm{~N}$ & 46 & 46 \\
\hline
\end{tabular}

Finally, analysis of interview data will be integrated into the "discussion" section to explain the findings of quantitative data. The interviews were transcribed and analyzed by the researcher. Content analysis was used for coding data and identifying categories within those data.

\section{DISCUSSION}

Through the process of answering the three research questions, the researcher encountered some important findings. First, Saudi teachers' beliefs about reading strategy instruction are in accordance with their teaching practices. Second, teachers' qualifications have no effect on their beliefs and attitudes toward reading strategy instruction.

However, the most important finding of this study was that "cognitive strategies are the only reading strategies practiced in Saudi classes". When asked to indicate their level of agreement on the teaching of reading strategies, Saudi EFL teachers agreed upon the importance of teaching the following reading strategies:

- Previewing the reading martial by thinking about the text, title, and pictures.

- Skimming and scanning the text.

- Guessing the meaning of unknown words. 
- Asking questions about the text before reading it

- Activating students' prior knowledge and experiences.

- Paraphrasing what students have read.

- Using context clues to help students understand what is being read.

- Using tables, figures, and pictures to increase understanding.

When we look carefully at these strategies, we can conclude the following:

1. These strategies fall into the three main categories of reading strategies: pre-reading, while-reading, and postreading. This supports the findings of Cabaroglu and Yurdaisik (2008) that EFL teachers prefer using pre-reading, while-reading, and post-reading strategies. However, the highest percentage $(50 \%)$ of these preferred strategies pertains to pre-reading strategies. While-reading and post-reading strategies are less likely to be practiced in Saudi reading classes.

2. When we re-examine the most preferred strategies according to their type (i.e, cognitive or metacognitive), we find that ALL of them are cognitive strategies. This is a very interesting finding that can be explained by the qualitative data obtained from interviews. The researcher found that $75 \%$ (three teachers) of the interviewed sample knew nothing or very little about metacognitive strategies. This finding also explains why participants ranked all metacognitive strategies within "neutral", which means "don't know," about the importance of the strategies mentioned (see Table 2).

When the researcher asked participants about reading strategies they prefer to teach, they mentioned the following:

- Skimming

- Scanning

- Using figures and tables

- Summarizing

Again, all of these strategies are cognitive, encouraging one to wonder why cognitive strategies are more prominent in Saudi classes than metacognitive strategies. Participants typically answered this question by saying that these strategies (cognitive) were the ones that were "taught during their preparation programs" and "suggested by teachers' manuals".

Moreover, the perception that teaching reading strategies reduces instructional time was also evident in participants' answers to the interview questions. All of the respondents indicated that they strongly agreed that teaching reading strategies, in general, is important, yet it consumes instructional time. One teacher mentioned that although he had some knowledge about metacognitive strategies, he tended not to teach them in class because they "are very difficult to explain", "there is no time", and "students are not motivated to learn them".

Data from surveys and observations confirmed the above findings that Saudi teachers perceive cognitive strategies as being vital in their teaching and thus tend to train/teach their students in using them. This result indicates that we, as EFL professors and teachers, should devise some solutions to the teachers' lack of knowledge about metacognitive reading strategies. The vast majority of research studies have confirmed that metacognitive reading strategies promote EFL reading comprehension. These strategies help students in connecting new information to former knowledge, selecting thinking strategies deliberately, planning, monitoring, and evaluating thinking processes (Baker \& Brown, 1984). Metacognitive strategies also regulate cognitive strategies, which most Saudi teachers practice in their reading classes.

Therefore, EFL teachers' preparation programs must be updated to include the most effective metacognitive reading strategies. EFL supervisors should also circulate readings, brochures, and research studies for teachers to read. In addition, they should plan training courses that teach and train teachers on the use of metacognitive reading strategies in classes. The current study recommends that in addition to cognitive reading strategies, teachers' preparation programs and training courses should train teachers in using the following metacognitive strategies:

- Stopping reading to check comprehension.

- Modifying new learning.

- Checking understanding when coming across conflicting information.

- Discussing one's reading with others to check understanding.

- Providing one's own feedback on what one has read.

- Making inferences and drawing conclusions.

- Comparing and contrasting information from one or more texts.

- Concentrating on the reading task.

- Regulating mood to stimulate the reading process.

- Analyzing and evaluating the information presented in the text.

- Engaging with the text.

- Integrating the information in the text with what one already knows.

- Completing graphic organizers such as Venn diagrams, KWL, etc.

\section{CONCLUSIONS}


The current study aimed to explore the attitudes of Saudi teachers toward teaching reading strategies and determine whether their practices in classes reflected their beliefs. The study also investigated the relationship between teachers' qualifications and their attitudes toward reading strategy instruction. The results of this study indicate that Saudi EFL teachers perceive cognitive reading strategies to be of great importance in reading classes. Therefore, they tend to teach their students how to skim, scan, guess the meaning of new words, and other cognitive strategies in each reading lesson. The study also revealed that teachers' beliefs have great influence on their practices in classes, which was evident in the Saudi teachers' cases. Finally, the study found that teachers' qualifications have no effect on their attitudes toward reading strategy instruction. The findings of this study urge EFL teachers in Saudi Arabia to learn more about metacognitive reading strategies so they can train their students in using them. EFL supervisors and professors in Saudi Arabia are also encouraged to incorporate both cognitive and metacognitive reading strategies in their in-service training programs.

\section{APPEndix (A) AtTitude SURVEY}

Dear EFL teacher / supervisor,

I am doing a research on the importance of teaching reading strategies in EFL classrooms. The study aims at examining EFL teachers' attitudes towards the explicit teaching of some metacognitive reading strategies in EFL classroom. I would like to ask for your assistance in my study by completing the following questionnaire. The information obtained from this study is of vital interest and importance to educators and students and teaching of English as a foreign language. I appreciate your taking some of your valuable time to fill out the questionnaire, which will take 15-20 minutes to complete. Your responses will not be traced to you and will remain completely confidential.

Please read each statement carefully and then, decide your answer, based on your own point of view, by checking the appropriate box.

How important is it to teach your EFL student to:

\begin{tabular}{|c|c|c|c|c|c|}
\hline \multirow[b]{2}{*}{ Strategies } & \multicolumn{5}{|c|}{ Degrees of Importance } \\
\hline & $\begin{array}{l}\text { Very } \\
\text { Important }\end{array}$ & Important & $\begin{array}{l}\text { Neutral } \\
\text { (Don't Know) }\end{array}$ & $\begin{array}{l}\text { Less } \\
\text { Important }\end{array}$ & $\begin{array}{l}\text { Not } \\
\text { Important at } \\
\text { all }\end{array}$ \\
\hline \multicolumn{6}{|l|}{$\begin{array}{l}\text { Preview the material by thinking about: the text, the title, and the } \\
\text { pictures. (Cog.) }\end{array}$} \\
\hline \multicolumn{6}{|l|}{ Have a purpose for reading. (met.) } \\
\hline \multicolumn{6}{|l|}{ Activate prior knowledge and experiences about the topic. (Cog.) } \\
\hline \multicolumn{6}{|l|}{ Skim and scan the text for information.(Cog.) } \\
\hline \multicolumn{6}{|l|}{ Ask questions about the text before reading it.(Cog.) } \\
\hline \multicolumn{6}{|l|}{ Write summaries to reflect on key ideas in the text. (Cog.) } \\
\hline \multicolumn{6}{|l|}{$\begin{array}{l}\text { Underline or circle information in the text to help student } \\
\text { remember it (Cog.) }\end{array}$} \\
\hline \multicolumn{6}{|l|}{ Stop reading to check comprehension.. (met.) } \\
\hline \multicolumn{6}{|l|}{$\begin{array}{l}\text { Use tables, figures, and pictures in text to increase } \\
\text { understanding.(Cog.) }\end{array}$} \\
\hline \multicolumn{6}{|l|}{$\begin{array}{l}\text { Use context clues to help students understand what is being read. } \\
\text { (Cog.) }\end{array}$} \\
\hline \multicolumn{6}{|l|}{ Paraphrase what students read .(Cog.) } \\
\hline \multicolumn{6}{|l|}{ Modify new learning.. (met.) } \\
\hline \multicolumn{6}{|l|}{$\begin{array}{l}\text { Check understanding when coming across conflicting } \\
\text { information. . (met.) }\end{array}$} \\
\hline \multicolumn{6}{|l|}{ Think aloud while reading.(Cog.) } \\
\hline \multicolumn{6}{|l|}{ Reread the problematic part.(Cog.) } \\
\hline \multicolumn{6}{|l|}{ Look up unknown words in a dictionary.(Cog.) } \\
\hline \multicolumn{6}{|l|}{ guess the meaning of unknown words or phrases. (Cog.) } \\
\hline \multicolumn{6}{|l|}{ Discuss one's reading with others to check understanding. . (met.) } \\
\hline \multicolumn{6}{|l|}{ Provide one's own feedback on what one has read.. (met.) } \\
\hline \multicolumn{6}{|l|}{ Make inferences and draw conclusions.. (met.) } \\
\hline \multicolumn{6}{|l|}{ Compare and contrast information from one or more texts. . (met.) } \\
\hline \multicolumn{6}{|l|}{ Concentrate on the reading task.. (met.) } \\
\hline \multicolumn{6}{|l|}{ Regulate mood to stimulate the reading process.. (met.) } \\
\hline \multicolumn{6}{|l|}{ Analyze and evaluate the information presented in the text. (met.) } \\
\hline \multicolumn{6}{|l|}{ Engage with the text.. (met.) } \\
\hline \multicolumn{6}{|l|}{$\begin{array}{l}\text { Integrate the information in the text with what students already } \\
\text { know . (met.) }\end{array}$} \\
\hline $\begin{array}{l}\text { Complete graphic organizers such as Venn diagram, KWL, etc.. } \\
\text { (met.) }\end{array}$ & & & & & \\
\hline
\end{tabular}

Thank you for your participation

Dr. Hashem Ahmed Alsamadani

Umm Al-Qura University, Dept. of Curiculum and Instruction

Email: drmazawid@gmail.com 


\section{REFERENCES}

[1] Akkakoson, S., \& Setobol, B. (2009). Thai EFL use of strategies in reading English texts. The Journal of KMUTNB, 19(3) 329342 .

[2] Aebersold, J., \& Field, M. (1997). From reader to reading teacher: Issues and strategies for second language classrooms. Cambridge: Cambridge University Press

[3] Baker, L., \& Brown, A. (1984). Metacognitive skills in reading. In D. Pearson, M. Kamil, R. Barr, \& P. Mosenthal (Eds.), Handbook of Reading Research (pp. 353-394). New York: Longman.

[4] Block, E. (1986). The comprehension strategies of second language readers. TESOL Quarterly, 20, 463-494.

[5] Cabaroglu, N. \& Yurdaisik, A. (2008). University instructors' views about and approaches to reading instruction and reading strategies. The Reading Matrix, 8 (2) 133-154. Retrieved July 15, 2011 from: www.readingmatrix.com/articles/cabarogluyurdaisik/article.pdf.

[6] Carrell, P., Pharis, B., \& Liberto, J. (1989). Metacognitive strategy training for ESL reading. TESOL Quarterly, 20, 463-494.

[7] Carrell, P. L. (1989). Metacognitive awareness and second language reading. TESOL Quarterly, 73, 121-134.

[8] Cubukcu, F. (2008). Enhancing vocabulary development and reading comprehension through metacognitive strategies. Issues in Educational Research, 18(1). Retrieved July 11, 2011 from www.iier.org.au/iier18/cubukcu.pdf.

[9] Davis, J. \& Bistodeau, L. (1993). How do L1 and L2 reading differ? Evidence from think aloud protocols. The Modern Language Journal, 77(4), 459-471.

[10] Devine, J. (1993). The role of metacognition in second language reading and writing. In G. Joan and L. I. Carson (Eds.), Reading in the composition classroom, second language perspective (pp. 105-130). Boston: Heinle and Heinle Publishers.

[11] Dole, J., Nokes, J., \& Drits, D. (2009). Cognitive strategy instruction. In S. E. Israel \& G. G. Duffy (Eds.), Handbook of research on reading comprehension (pp. 347-372)., New York, NY: Routledge.

[12] Flavell, J. (1981). Cognitive monitoring. In W. P. Dickson (Ed.), Children's oral communication skills (pp. 35-60). New York: Academic Press.

[13] Haas, C., \& Flower, L. (1988). Rhetorical reading strategies and the construction of meaning. College Composition and Communication. 39, 167-83.

[14] Hamp-Lyons, E. (1985). Two approaches to teaching reading: A classroom-based study. Reading in a Foreign Language, 3. 363-73.

[15] Israel, S., E. (2007). Using metacognitive assessments to create individualized reading instruction. International reading association. Newark, DE: International Reading Instruction.

[16] Mikulecky, B.S. (1985). Reading skills instruction in ESL. In P. Larson, E.L. Judd, \& D.S. Messerschmitt (Eds.), On TESOL '84. A Brave New World for TESOL (pp. 261-277). Washington, DC: TESOL.

[17] Mizumoto, A. \& Takeuchi, O. (2009). Examining the effectiveness of explicit instruction of vocabulary learning strategies with Japanese EFL university students. Language Teaching Research, 13 (4)425-449.

[18] Pakenham, K. (1984). Developing expectations for text in adult beginning ESL readers. In J. Handscombe, R.A. Orem, \& B.P. Taylor (Eds.), On TESOL '83: The Question of Control (pp. 149-161). Washington, DC: TESOL.

[19] Palincsar, A., \& Brown, L. (1984). Reciprocal teaching of comprehension-monitoring activities. Cognition and Instruction, $1(2), 117-175$

[20] Park, T. \& Osborne, E. (2006). A griscience teachers' attitudes toward implementation of content area reading strategies. Journal of Agricultural Education, 47(4), 39-51. Retrieved June 10, 2011 from http://pubs.aged.tamu.edu/jae/pdf/Vol47/47-04039.pdf.

[21] Pressley, M., \& Afflerbach, P. (1995). Verbal protocols of reading: The nature of constructively responsive reading. Hillsdale, NJ: Erlbaum.

[22] Rasekh, Z., \& Ranjbary, R. (2003). Metacognitive strategy training for vocabulary learning. TESL-EJ, 7(2) Retrieved July 11, 2011 from http://www.tesl-ej.org/wordpress/issues/volume7/ej26/ej26a5/.

[23] Spencer, V. Carter, B., Boon, R., Simpson-Garcia, C. (2008). If you teach-you teach reading. International Journal of Special Education, 23(2), 1-7.

[24] Squires, D., \& Bliss, T. (2004). Teacher visions: navigating beliefs about literacy learning: teachers can use 'visioning' as a tool to clarify how their beliefs play out as instructional practices. The Reading Teacher, 57 (8), 756-763.

[25] Susser, B., \& Robb, T. (1990). EFL Extensive Reading Instruction: Research and Procedure. JALT, 12 (2), Retrieved June 14 , 2011, from http://www.cc.kyoto-su.ac.jp/ trobb/sussrobb.html.

[26] Wichadee, S. (2011). The Effects Of Metacognitive Strategy Instruction On EFL Thai Students' Reading Comprehension Ability. Journal of College Teaching and Learning, 8 (5) 10-31.

Hashem Ahmed Alsamadani is a former EFL teacher and supervisor at Saudi intermediate and secondary schools . He graduated with a $\mathrm{PhD}$ in reading education and language arts education from Ohio University in 2009. Dr. Alsamadani now works as an assistant professor of TESOL at Umm Alqura University, teaching courses on EFL curriculum and methodology at bachelor's and master's levels. His research area of interest includes integrating technology into FL instruction, self-regulation / metacognition and foreign language learning, and ESL/EFL teachers' training needs. 